\title{
PREKYBOS VADOVU VEIKSMINGO MOKYMOSI GALIMYBĖS PROFESIONALUMO TOBULINIMO KONTEKSTE
}

\author{
Rūta Marija Andriekienė, Gitana Tolutienė, Jūratė Kontautienė \\ Klaipédos universitetas
}

\begin{abstract}
Anotacija
Straipsnyje teoriškai išanalizavus darbuotojų veiksmingą mokymąsi ir jo plètros galimybes profesionalumo tobulinimo kontekste tiriamas prekybos vadovų požiūris ị tai. Empiriškai (prekybos vadovų požiūriu) atskleista ir pagrista profesionalumo tobulinimo, veiksmingo mokymosi samprata ir esmè, veiksmingo mokymosi ir profesionalumo tobulinimo strategijos bei būdai, profesionaliai prekybos vadovų veiklai būtinos kompetencijos, profesionalumo tobulinimo galimybès ir kt. Remiantis pagrindinių tyrimo rezultatų analize ir išvadomis, straipsnyje pateikiama siūlymų mažmeninès prekybos įmonès vadovams.

PAGRINDINIAI ŽODŽIAI: profesionalumas, veiksmingas, mokymasis, perspektyva, tobulinimas, prekybos vadovas.
\end{abstract}

\begin{abstract}
The article analyzes the scientific problem of effective learning opportunities for trade supervisors' in the perspective of professionalism improvement. Selected as research object trade supervisor's effective learning and professionalism improvement. After theoretically analyse workers' effective learning and the possibilities of its development perspective of professionalism improvement analysed trade supervisor's view on effective learning opportunities from the perspective of professionalism improvement. In this article, the empirical aspect (from the point of view of trade supervisor's) reveals and substantiates the concept and essence of professionalism improvement and effective learning, strategies and methods of effective learning and professionalism improvement, trade supervisor's competencies necessary for professional activities, opportunities for effective learning of trade supervisor's of professionalism improvement, etc. Based on the analysis and conclusions of the main research results, the article presents suggestions for the managers of a retail company.

KEY WORDS: proffesionalism, effective, learning, perspective, improvement, trade supervisor.
\end{abstract}

DOI: http://dx.doi.org/10.15181/tbb.v85i2.2191

\section{Ivadas}

Šiandien mokslinio ir praktinio pobūdžio dialoguose akcentuojamas darbuotojų igūdžių, profesionalumo tobulinimas, organizacijos mokymosi kultūra, turimo potencialo atskleidimas, siekiant, kad organizacija sėkmingai veiktų dabar ir ateityje, būtų pranašesnè konkurencingoje rinkoje. Todèl šiuolaikinė sėkminga organizacija siekia turèti nuolat tobulèti linkusius darbuotojus profesionalus. Vis dèlto padèti ugdytis darbuotojų profesionalumą, žvelgiant ì perspektyvą, organizacijoje ne taip paprasta. İmonès turètų susitelkti ties perspektyvių, veiksmingų mokymosi programų kūrimu, kad darbuotojai greitai ir veiksmingai 
mokytųsi, siektų profesionalumo, didintų darbinès veiklos vertę ir darbo našumą. Sèkmingai veikia profesionalus ugdančios, t. y. igūdžius, gebejjimus ilgalaikèje perspektyvoje tobulinančios, įmonès.

B. Jatkauskienès (2013) teigimu, profesionalumas nèra stabilus, jis nuolat konstruojamas, atsižvelgiant ị profesinès veiklos reikmes, ir palengvina darbuotojo adaptaciją profesinès krizès atveju. Taigi, norint vystyti ir plètoti darbuotojų profesionalumą, reikia surasti bei ištirti veiksmingo mokymosi strategijas ir būdus, tam įtaką darančius veiksnius. Tad vienas svarbiausių mokymosi veiksmingumo požymių - mokymosi kultūros formavimas. Mokymasis turètų būti ne proginis, o strateginis dalykas, turint ilgalaikių tikslų. Tinkamai parinkti mokymai tiek darbuotojams, tiek įmonei padeda atrasti įvairių problemų sprendimų, ne tik tiesioginių ịmonei (didina finansinius veiklos rodiklius, gerina darbuotojų veiklos rezultatus ir kt.), bet ir darančių motyvacini poveiki darbuotojams (didina jų pasitikejjimą savo jègomis, ugdo ịūdžius, sudaro galimybes siekti karjeros, didina lankstumą, leidžia darbuotojams pajusti savo reikalingumą, visa tai lemia pasitenkinimą darbu). Be to, jie garantuoja organizacijos narių reikiamo kvalifikacijos lygio palaikymą.

Norint veiksmingai mokytis svarbiausia yra vidinè motyvacija. Taigi organizacijos, siekdamos darbuotojų profesionalumo, kuris užtikrina organizacijos veiklos sèkmingumą, turètų sudaryti veiksmingo darbuotojų mokymosi sąlygas ir nuolat skatinti juos mokytis, siekiant tobulinti profesionalumą. Kad mokymasis būtų veiksmingas ir pasitarnautų profesinei veiklai, jis turi būti tikslingas, nenutrūkstamas, sistemingas, tai padètų organizacijai spręsti problemas, atsinaujinti. Taigi svarbu nuolat darbuotojus skatinti ugdytis profesionalumą, ieškant veiksmingų mokymosi būdų, nustatant jiems ịtakos turinčius veiksnius, skatinant mokymosi motyvaciją, kt. Šiame straipsnyje svarbu nustatyti prekybos vadovų mokymosi veiksmingumo, neatsiejamo nuo vidinių vertybinių nuostatų bei profesineje veikloje ir gyvenime kylančiu iššūkių, galimybes profesionalumo tobulinimo kontekste.

Pastebėta, kad moksliniuose šaltiniuose plačiai analizuojamas suaugusiujų švietimas, mokymasis, mokymo strategijos ir būdai bei mokymąsi lemiantys veiksniai (Adomaitienè ir kt., 2020; 2016; Паронджанов, 2017; Bagdonienè ir kt., 2017; Greene, 2016; Stelmokienè ir kt., 2015; Syed, 2015; Tolutiené, 2014; Merriam, 2013; Brookfield, 2013; Jatkauskienè ir kt., 2015; 2013; Jatkauskiené, 2013 ir kt.). Ypač vertingi B. Jatkauskienès (2013) sisteminiai tyrimai andragogu profesionalizacijos aspektu, analizuojant prekybos vadovų veiksmingo mokymosi galimybes profesionalumo tobulinimo kontekste. Mokslinès literatūros analizė atskleide, kad prekybos vadovų mokymosi veiksmingumas profesionalumo tobulinimo kontekste nepakankamai išanalizuotas. Tad straipsnyje formuluojama 
Rūta Marija Andriekienè, Gitana Tolutienė, Jūratė Kontautienè

mokslinè problema - prekybos vadovų veiksmingo mokymosi galimybès profesionalumo tobulinimo kontekste.

Tyrimo objektas: prekybos vadovų veiksmingas mokymasis ir profesionalumo tobulinimas.

Tyrimo tikslas: ištirti veiksmingo mokymosi galimybes profesionalumo tobulinimo kontekste prekybos vadovų požiūriu.

Tyrimo tikslo siekta, atskleidžiant prekybos vadovų požiūị ị: 1) profesionalumo tobulinimo, veiksmingo mokymosi sampratą ir esmę; 2) veiksmingo mokymosi ir profesionalumo tobulinimo strategijas ir būdus; 3) kompetencijas, būtinas prekybos vadovu profesionaliai veiklai; 4) prekybos vadovų veiksmingo mokymosi galimybes profesionalumo tobulinimo aspektu.

Tyrimo metodai. Atlikus veiksmingo darbuotojų mokymosi galimybiu profesionalumo tobulinimo kontekste teorinę analizę, vykdyta apklausa (anketavimas), siekiant ištirti prekybos vadovų požiūrị ị veiksmingo mokymosi galimybes profesionalumo tobulinimo aspektu.

\section{Prekybos vadovų veiksmingo mokymosi galimybių profesionalumo tobulinimo aspektu tyrimo rezultatų analizė ir interpretacija}

Tyrimo metodologija, metodika ir organizavimas. $2020 \mathrm{~m}$. vasario mèn. vykdytas empirinis tyrimas, siekiant ištirti prekybos vadovų požiūrị ị veiksmingo mokymosi galimybes profesionalumo tobulinimo aspektu. Tyrimas atliktas pasitelkus anketinę apklausą. Anketos klausimynas sudarytas, remiantis teorine analize (Adomaitienè ir kt., 2016; Gedvilienè ir kt., 2015; Jatkauskienè ir kt., 2015; 2013; Lukošūnienė, 2014; Tolutienė, 2014; Andriekienè ir kt., 2011 ir kt.), straipsnio autoriams parengus klausimus ir atsakymų variantus. Klausimyną sudarẻ 27 mišrūs klausimai su atsakymų variantais, jie suskirstyti ị šešias dalis: 1) socialiniai-demografiniai duomenys: lytis, amžius, išsilavinimas, specialybė, darbo stažas (1-5 kl.); 2) profesionalumo tobulinimo, veiksmingo mokymosi samprata ir esmè (6-14 kl.); 3) veiksmingo mokymosi ir profesionalumo tobulinimo strategijos bei būdai (15-19 kl.); 4) profesionaliai veiklai būtinos prekybos vadovo kompetencijos (20-22 k1.); 5) prekybos vadovo veiksmingo mokymosi galimybès profesionalumo tobulinimo aspektu (23-24 k1.); 6) prekybos vadovų pasiūlymai, pageidavimai veiksmingo mokymosi, siekiant tobulinti profesionalumą, kontekste (25-27 kl.).

Klaipėdos regione iš viso dirba maždaug 800 mažmeninės prekybos vadovų. Iš jų apklausta 10 proc. Išdalinta 80 anketų, analizei panaudota 70 iš jų. Siekiant parinkti reprezentatyviają imtị, kuri atskleistų generalinę aibę, tyrimui pasirinkta paprastoji atsitiktinè imtis. Atrinkti lengviausiai pasiekiami prekybos vadovai 
ir organizacijos, kurių vadovai ị atliekamą tyrimą žvelgè geranoriškai. İ tyrimą ịtraukti prekybos vadovai, dirbantys mažmeninès prekybos įmonėse, kurios veikia skirtingose vietovėse, skiriasi jų apyvarta, darbuotojų skaičius, įsteigimo laikas ir kt. Siekta, kad tyrimo imtis apimtų kuo įvairesnius tiriamo reiškinio atvejus, siekiant nustatyti bendrus, visiems tiriamiems atvejams būdingus bruožus. Visiems dalyvaujantiesiems šiame tyrime užtikrintos vienodos sąlygos.

Duomenys analizuoti taikant statistinę duomenų apdorojimo programą SPSS 26.0. Tyrimo atsakymai pateikti procentine išraiška. Taikyti šie statistiniai metodai: 1) dažnių lentelès; 2) grafinè analizė - sisteminti duomenis ir aprašyti dažnių skirstymą; 3) dviejų kintamujų ryšių vertinimas (Spearmano koreliacijos koeficientas, matuojantis tiesinę kintamujų priklausomybę); 4) siekiant palyginti pagal amžių, stažą ir išsilavinimą, sudarytos kryžminès lentelès; 5) ranginiams kintamiesiems apskaičiuotos aprašomosios statistikos charakteristikos (vidurkis, standartinis nuokrypis, minimalios ir maksimalios reikšmès). Gauti duomenys susisteminti, išanalizuoti ir palyginti tarpusavyje. Statistiškai reikšmingiems skirtumams tarp grupių nustatyti taikytas $\chi^{2}$ kriterijus, pasirinktas reikšmingumo lygmuo ne didesnis nei 0,05 .

Straipsnyje atlikta koreliacinè analizė, siekiant nustatyti statistiškai reikšmingus koreliacinius ryšius tarp šių kintamujų: kompetencijų vertinimo ir išsilavinimo; kompetencijų svarbos ir darbo stažo bei amžiaus; kompetencijų tobulinimo dažnio ir amžiaus, išsilavinimo bei darbo stažo; noro tobulinti kompetencijas, atsižvelgiant i amžių, ir išsilavinimo ar darbo stažo. Šiame straipsnyje pateiktos ir detalizuotos tik reikšmingos porinès koreliacijos.

Prekybos vadovų požiūris į veiksmingo mokymosi galimybes profesionalumo tobulinimo as pektu. Tyrimo dalyvių socialinių-demografinių duomenų analizè atskleidé, kad didžiausią dali - 70 proc. dalyvavusiųjų tyrime sudaro moterys, likusieji - vyrai. Tiriamają imtị sudaro respondentai iš ịvairių amžiaus grupių, didžioji dalis (68,6 proc.) - 31-45 m. amžiaus, maždaug ketvirtadali (21,4 proc.) sudaro $46 \mathrm{~m}$. ir vyresni asmenys, mažiausią dali (10 proc.) - respondentai iki $30 \mathrm{~m}$. amžiaus. Taigi tyrimo dalyvių daugumą sudaro vidutinio amžiaus prekybos organizacijų vadovai, turintys galimybę tobulinti savo profesines kompetencijas. Galima daryti prielaidą, kad šis amžius - tai darbingo amžiaus pikas, kai siekiama užsitikrinti asmeninị ir profesinị gyvenimą, aktyviai siekti karjeros bei tobulinti savo profesionalumą. Respondentų pasiskirstymo pagal profesiją analizè atskleide, kad net 71,1 proc. tiriamujų yra ịgiję vadybinị išsilavinimą. Taigi didžiosios dalies respondentų igyta profesija atitinka darbo pobūdị.

Daugiausia (47,1 proc.) respondentų nurodè, kad turi aukštaji universitetini išsilavinimą (bakalauro laipsnị), nemaža dalis (22,9 proc.) turi magistro laipsnị. 
Taigi šios profesijos atstovai siekia nuolat tobulinti savo profesionalumą. Nustatyta, kad didžioji dalis (67,1 proc.) respondentų turi didesnį nei $11 \mathrm{~m}$. darbo stažą. Galima daryti prielaidą, kad daugelis dirba nebe pirmus metus, turi aukštaji išsilavinimą ir suvokia, kokių kompetencijų jiems trūksta, tad stengiasi tobulèti, siekdami tapti savo srities profesionalais.

Atliekant tyrimą nustatyta, kad didžioji dalis (40 proc.) respondentų profesionalumą supranta kaip nuolatinị specialių mokslo žinių kaupimą, profesinei veiklai būtinų kompetencijų ịgijimą ir tobulinimą. Apklausti prekybos vadovai profesionalumą suvokia kaip kompetencijų igijimą kaupiant profesinę patirtį. Pasak B. Jatkauskienès (2013), ši profesionalizacijos, kaip vidaus proceso, dimensijos prasmė gali reikštis įvairiai: specifinių profesinių žinių mobilizavimu, tęstiniu profesiniu mokymu, iš praktikos kilusių žinių formalizavimu ir pan. Kiek mažiau (31,4 proc.) respondentų nurodè, kad profesionalumas - tai darbo išmanymas, gebėjimas produktyviai veikti. Šie prekybos vadovai suvokia, kad būtina ịgyti specialių profesinių žinių ir kompetencijų, kurios toliau būtų gilinamos bei pritaikomos praktiškai (1 lentelè).

1 lentelé. Respondentų pasirinkta profesionalumo samprata

\begin{tabular}{|c|c|c|}
\hline \multirow{2}{*}{ Profesionalumo samprata } & \multicolumn{2}{|c|}{ Atsakymai } \\
\hline & $n$ & proc. \\
\hline $\begin{array}{l}\text { Profesionalumu laikomas mokejjimas produktyviai veikti, veiklos } \\
\text { išmanymas, neturint specialiųjų žinių ar bazinio pasirengimo }\end{array}$ & 10 & 14,3 \\
\hline $\begin{array}{l}\text { Nuolatinis specifinių, mokslo žinių kaupimas, profesinei veiklai } \\
\text { būtinų kompetencijų ịijimas ir tobulinimas }\end{array}$ & 28 & 40,0 \\
\hline Darbo išmanymas, gebejjimas produktyviai veikti & 22 & 31,4 \\
\hline $\begin{array}{l}\text { Asmens turimų igūdžių, gebėjimų panaudojimas konkrečioje } \\
\text { veiklos situacijoje }\end{array}$ & 11 & 15,7 \\
\hline $\begin{array}{l}\text { Profesionalumas nėra stabilus, jis nuolat konstruojamas, } \\
\text { vystomas, nulemtas veiklos, prisitaiko prie pokyčių }\end{array}$ & 19 & 27,1 \\
\hline $\begin{array}{l}\text { Aukšto lygio žinių, kompetencijų ir veiklos kokybės } \\
\text { demonstravimas }\end{array}$ & 16 & 22,9 \\
\hline $\begin{array}{l}\text { Gebejjimai, žinios, kultūra ir tapatumas, siejami su aukštu } \\
\text { profesinių žinių lygiu, kartais labai specializuotomis žiniomis, } \\
\text { veiklos metodais, uždara darbo rinka, veiklos procesų valdymu } \\
\text { ir kt. }\end{array}$ & 16 & 22,9 \\
\hline
\end{tabular}

Respondentų nuomone, profesionalumą lemia du pagrindiniai veiksniai: nuolatinis, sistemingas, tikslingas ir veiksmingas mokymasis žvelgiant i perspektyvą (70 proc.) ir nuolatinis kvalifikacijos tobulinimas, tobulejimo siekis (51,4 proc.) (2 lentelè). Vadinasi, prekybos vadovai, kaip profesionalai, suvokia ir prisiima atsakomybę už mokymąsi, kuris žvelgiant ị ateitị skatina nuolat tobulèti ir 
taip lemia profesionalumą. Vertinant tai, kaip suvokiamas profesinis tobulejimas, atsižvelgiant ị amžių, galima pastebèti, kad jauniausiai tiriamujų amžiaus grupei (iki $30 \mathrm{~m}$.) profesionalumą lemiantis veiksnys - priklausymas savajai profesijos atstovų bendruomenei - didžiausias $(28,6$ proc.) tarp kitų amžiaus grupių. Taigi jauniems prekybos vadovams svarbu priklausyti savajai profesijos atstovų bendruomenei, nes tai rodo jų profesionalumo lygị. Kaip teigia B. Jatkauskienè (2013), savajai profesijos atstovų bendruomenei priklausantis profesionalas, ịsitraukęs ị profesinę veiklą ir reguliuojamas profesijos vidaus atstovų, yra „tikras“ profesionalas.

2 lentele. Respondentų pasiskirstymas pagal profesionalumą lemiančius veiksnius

\begin{tabular}{|l|l|l|}
\hline \multirow{2}{*}{ Veiksniai, lemiantys veiksmingo profesionalumo tobulinimą } & \multicolumn{3}{|c|}{ Atsakymai } \\
\cline { 2 - 3 } & \multicolumn{1}{|c|}{$\boldsymbol{n}$} & \multicolumn{1}{c|}{ proc. } \\
\hline Mokymosi tikslų išsikèlimas & 10 & 14,3 \\
\hline $\begin{array}{l}\text { Nuolatinis, sistemingas, tikslingas ir veiksmingas mokymasis, } \\
\text { žvelgiant í perspektyvą }\end{array}$ & 49 & 70,0 \\
\hline Nuolatinis kvalifikacijos tobulinimas, tobulejimo siekis & 36 & 51,4 \\
\hline Priklausymas savajai profesijos atstovų bendruomenei & 7 & 10,0 \\
\hline Profesijos igijimas ir nuolatinis jos tobulinimas & 10 & 14,3 \\
\hline Asmens adaptacija ištikus profesinei krizei & 8 & 11,4 \\
\hline
\end{tabular}

65,7 proc. tiriamujų įsitikinę, kad profesionalas yra tas, kurị tokị esant pripažista tiek jis pats, tiek ir kiti. Tai rodo, kad nepakanka pačiam individui laikyti save profesionalu $(0,0$ proc.), jo profesionalumą turi pripažinti kolegos, vadovai, pavaldiniai, klientai ir kt. Kai kurių tyrëjų nuomone (Jatkauskienė ir kt., 2012, p. 54), vienas iš etapų, kai asmuo tampa tikru profesionalu, - profesinè integracija. Tos pačios patirties, žinių, net problemų bendrumas leidžia tapatintis su konkrečia profesine grupe. Kad būtų pripažintas, atrastų save ar apsisaugotų, individas ne kartą turès tapatinsis su kitais, tačiau kiekvieną kartą jis privalès vèl tapti pats savimi. Todèl galima teigti, kad profesionalai turi pabrèžti savo unikalumą, skirtingumą, nepriklausomybę nuo grupès. Nuolat tobulëjančio ir save pažįstančio asmens pagrindu formuojasi profesinis tapatumas. Šiais dviem aspektais prekybos vadovai tampa profesionalais konstruodami ir tobulindami savo profesionalumą.

Atliekant tyrimą aiškinantis, kas atskleidžia prekybos vadovo profesionalumą, nustatyta, kad daugiausia (65,7 proc.) respondentų pasirinko atsakymą „lankstumas priimant pokyčius, gebejjimas savo patirtị pritaikyti kintančiose veiklos situacijose“, kita dalis (55,7 proc.) - „gebejjimas planuoti, organizuoti, vykdyti, vertinti savo veiklą،", nemažai tiriamujų ( 47,1 proc.) pasirinko atsakymą „kritinis mąstymas, problemų nustatymas ir kūrybiškas sprendimas“ (3 lentelè). Visi šie atsakymai atskleidžia, kad prekybos vadovų profesionalumą rodo aukštesnio 
lygio profesinè veikla ir tam tikras kokybès lygmuo. Kita vertus, norint išsilaikyti nuolat kintančioje darbo rinkoje ir didinti savo darbo našumą konkurencinejje verslo aplinkoje, neužtenka vien veiksmingai vadovauti pagal tikslias taisykles arba turèti žinių, lankstumas vykdant savo veiklą tampa vienu pagrindinių ịmonių siekiu. Empiriniai duomenys patvirtina, kad lankstumas, gebejjimas savo patirti pritaikyti kintančioje veiklos situacijoje, ieškoti nauju galimybių ir jas sudaryti parodo aukščiausio lygio prekybos vadovo profesionalumą.

3 lentele. Respondentų pasiskirstymas

prekybos vadovo profesionalumo supratimo aspektu

\begin{tabular}{|c|c|c|}
\hline \multirow{2}{*}{ Prekybos vadovo profesionalumas } & \multicolumn{2}{|c|}{ Atsakymai } \\
\hline & $n$ & proc. \\
\hline $\begin{array}{l}\text { Profesijos žinių turèjimas, taisyklių žinojimas, îvaldymas, taikymas } \\
\text { praktikoje }\end{array}$ & 20 & 28,6 \\
\hline $\begin{array}{l}\text { Nuolatinis žinių atnaujinimas, kompetencijų ir profesionalumo } \\
\text { tobulinimas }\end{array}$ & 30 & 42,9 \\
\hline $\begin{array}{l}\text { Lankstumas priimant pokyčius, gebejjimas savo patirti pritaikyti } \\
\text { kintančioje veiklos situacijoje }\end{array}$ & 46 & 65,7 \\
\hline Profesine praktika ir elgsena & 10 & 14,3 \\
\hline Refleksijos igūdžiai ir mokymosi veikiant gebėjimai & 10 & 14,3 \\
\hline Kritinis mąstymas, problemų nustatymas ir kūrybiškas sprendimas & 33 & 47,1 \\
\hline Mokymasis iš patirties, veiklos analizè ir tobulinimas & 24 & 34,3 \\
\hline Gebèjimas planuoti, organizuoti, vykdyti, vertinti savo veiklą & 39 & 55,7 \\
\hline Inovacijų ir modernių technologijų taikymas praktinèje veikloje & 15 & 21,4 \\
\hline Rezultatyvi veikla, tikslų išsikèlimas ir jų igyvendinimas & 27 & 38,6 \\
\hline
\end{tabular}

Nustatyta, kad daugelis (72,9 proc.) prekybos vadovų ịsitikinę, jog profesionalumo siekis leidžia realizuoti save ir asmeniškai tobulèti; nemažai (54,3 proc.) apklaustujų nurodè, kad tai skatina apčiuopiami jų darbo rezultatai; mažiausia dalis ( 15,7 proc.) mano, kad savo profesionalumą tobulina, siekdami išsaugoti darbo vietą (4 lentelè). Remdamiesi šiais duomenimis, galime daryti išvadą, kad prekybos vadovams, kaip profesionalams, labai svarbu save realizuoti ir asmeniškai tobulèti bei matyti savo darbo rezultatus. Vadinasi, jie turi poreikị tobulinti savo profesionalumą. G. Le Boterf'as (2010) ir B. Jatkauskienè (2013) teigia, kad vystymosi, tobulëjimo aspektu asmuo tampa profesionalu, kai išsiskiria savo turimomis kompetencijomis, asmeninėmis savybėmis, siekiais, pasirengimu siekti profesionalumo, individualiai tobulèti. Esant tam tikroms aplinkybėms profesinis tobulëjimas gali būti asmeninio tobulèjimo sinonimas. Tad nekeista, kad dalis prekybos vadovų, dirbančių mažmeninëje prekyboje, siekdami užtikrinti sẻkmingą veiklą, tobulina savo profesionalumą, nes tai skatina darbo rezultatai, lemiantys verslo gyvavimą. 
PREKYBOS VADOVŲ VEIKSMINGO MOKYMOSI GALIMYBĖS PROFESIONALUMO...

4 lentele. Respondentų pasiskirstymas priežasčių,

kas skatina siekti profesionalumo, aspektu

\begin{tabular}{|l|l|l|}
\hline \multicolumn{1}{c}{ Profesionalumo tobulinimo motyvai } & \multicolumn{2}{c|}{ Atsakymai } \\
\cline { 2 - 3 } & $\boldsymbol{n}$ & \multicolumn{1}{c|}{ proc. } \\
\hline Asmeninės karjeros sėkmė & 23 & 32,9 \\
\hline Galimybė realizuotis ir asmeniškai tobulèti & 51 & 72,9 \\
\hline Vadovų, kolegų įvertinimas & 14 & 20,0 \\
\hline Matomi asmeniniai darbo rezultatai & 38 & 54,3 \\
\hline Konkurencija (karjeros, veiklos atžvilgiu) & 18 & 25,7 \\
\hline Siekis išsaugoti darbo vietą & 11 & 15,7 \\
\hline
\end{tabular}

5 lentelèje pateikti apklausos rezultatai atskleidè, kad prekybos vadovams asmeniškai naudinga ir būtina tobulinti profesionalumą dèl trijų priežasčių, siekiant: prisitaikyti prie prekybos rinkos pokyčių (55,7 proc.); igyti naujų ir tobulinti turimas kompetencijas bei jas taikyti veikloje (55,7 proc.); asmeninio tobulejimo ir pasitenkinimo (47,1 proc.). Galima teigti, kad prekybos vadovai igyvendina savo tikslus, jeigu nuolat tobulèja, auga profesiniu požiūriu. Todèl svarbu suprasti, kad profesionalu tampama praktiškai dirbant. Sudètingoje, besikeičiančioje verslo aplinkoje keičiasi ir strateginiai organizacijos tikslai, prekybos vadovams savo veiklą tenka koreguoti. Svarbu suvokti ir tai, kad profesionalumą atskleidžia gebejjimas nutiesti veiksmingus ryšius tarp turimų kompetencijų ir atliekamos veiklos. Kuo daugiau žmonės mokosi, tuo daugiau patirties jie igyja, tad auga ir keičiasi. Nuo prekybos vadovo profesionalumo priklauso jo profesinès veiklos sėkmè. Todèl prekybos vadovas privalo nuolat mokytis, tobulèti tiek kaip asmuo, tiek kaip profesionalas.

5 lentele. Respondentų pasiskirstymas asmeninių profesionalumo tobulinimo siekių aspektu

\begin{tabular}{|c|c|c|}
\hline \multirow{2}{*}{ Naudinga ir būtina tobulinti profesionalumą } & \multicolumn{2}{|c|}{ Atsakymai } \\
\hline & $n$ & proc. \\
\hline Siekiant prisitaikyti prie nuolatinių prekybos rinkos pokyčių & 39 & 55,7 \\
\hline Norint darbe labiau savimi pasitikèti & 14 & 20,0 \\
\hline Siekiant sėkmingos karjeros & 16 & 22,9 \\
\hline $\begin{array}{l}\text { Siekiant igyti naujų ir tobulinti turimas kompetencijas bei jas } \\
\text { taikyti veikloje }\end{array}$ & 39 & 55,7 \\
\hline Siekiant asmeniškai tobulèti ir tuo pasitenkinti & 33 & 47,1 \\
\hline Siekiant vadovų, kolegų, pavaldinių ir kitų pripažinimo & 8 & 11,4 \\
\hline Siekiant didesnio darbo užmokesčio & 26 & 37,1 \\
\hline Baiminantis netekti darbo, esant didžiulei konkurencijai & 3 & 4,3 \\
\hline
\end{tabular}


Kaip matyti 6 lentelèje, 61,4 proc. tiriamųų veiksmingą mokymąsi supranta kaip mokymąsi taikant naujausius metodus, panaudojant nuolat atsinaujinančias žinias, ịgyjant naujų ịgūdžių, keičiant turimas nuostatas; 52,9 proc. - kaip iš įvairių mokymų, seminarų, kursų gautų žinių praktinį taikymą. Galima daryti prielaidą, kad tokị rezultatų pasiskirstymą lėmé poreikis nuolat tobulèti, domėtis naujovėmis ir joms diegti naujų darbo metodų taikymas vis atsinaujinant technologijoms, darbo metodikoms, veikiant kitiems veiksniams. Mažiausiai atsakiusiujų (14,30 proc.) nurodè, kad veiksmingas mokymasis - tai mokymasis iš patirties, kasdienès profesinès veiklos; 20 proc. atsakiusiųu teigimu, tai procesas, kai transformuojant patirti kuriamos žinios, lavinami gebejjimai, kitaip tariant, tai patirtinis mokymasis. Kai kurių tyrejų teigimu (Jatkauskienè, 2013, p. 332), vis spartẻjantis naujų technologijų diegimas gali būti pavojingas, vien mokymasis visų veiklos problemų neišspręs. Individuali patirtis mokantis naudinga tik tada, kai ji konceptualizuota, susieta su žiniomis, tai nuolat vykstantis procesas. Galima teigti, kad profesionalas mokosi iš patirties ir žino, kaip atlikti veiksmą, kad šis duotu norimą rezultatą. Praktiškai veikdami profesionalai sukuria asmenines praktines žinias, kurios skiriasi nuo ịvairiuose mokymuose pateikiamų deklaratyvių žinių. Taigi, remiantis tyrimo duomenimis, galima suprasti, kad nemaža dalis prekybos vadovų negeba susieti žinių su savo praktika, tad jiems refleksijos gebejjimų ugdymas būtinas kaip profesionalios veiklos sąlyga, norint veikti savarankiškai. Žinoma, žinios kaupiamos, bet reflektuojančiam praktikui mokymasis igauna pridètinę vertę, nes jo veikla neatsiejama nuo turimų konceptualių struktūrų, kurios susiformuoja laikui bėgant iggaunant patirties ir sukaupus žinių.

6 lentele. Respondentų pasirinkta veiksmingo mokymosi samprata

\begin{tabular}{|c|c|c|}
\hline \multirow{2}{*}{ Veiksmingo mokymosi supratimas } & \multicolumn{2}{|c|}{ Atsakymai } \\
\hline & $n$ & proc. \\
\hline Mokymasis iš patirties, kasdienès profesinès veiklos & 11 & 14,3 \\
\hline $\begin{array}{l}\text { Gautų žinių iš įvairių mokymų, seminarų, kursų taikymas } \\
\text { praktikoje }\end{array}$ & 40 & 52,9 \\
\hline $\begin{array}{l}\text { Mokymasis, taikant naujausius metodus, panaudojant nuolat } \\
\text { atsinaujinančias žinias, igyjant naujų igūdžių, keičiant nuostatas }\end{array}$ & 46 & 61,4 \\
\hline Veiksmingas naujovių diegiamas darbinèje praktikoje & 25 & 35,7 \\
\hline $\begin{array}{l}\text { Profesionaliai organizuotas mokymosi procesas, kai žinios tampa } \\
\text { igūdžiais }\end{array}$ & 25 & 35,7 \\
\hline $\begin{array}{l}\text { Procesas, kai transformuojant patirtị kuriamos žinios, lavinami } \\
\text { gebejjimai }\end{array}$ & 7 & 20,0 \\
\hline
\end{tabular}

Beveik pusė (47,1 proc.) prekybos vadovų nurodè, kad mokymosi veiksmingumą lemia motyvacija tikslingai ịsisąmoninti mokymosi turinį; mažiau (42,9 proc.) apklaustụjų nurodė tinkamai iškeltus mokymosi tikslus (žr. 7 lentelę). 
Mokslinèje literatūroje (Jatkauskienė ir kt., 2015; Lukošūnienė, 2014 ir kt.) motyvacija įvardijama kaip vienas svarbiausių prasmingo mokymosi elementų, kaip kompleksinis reiškinys, apimantis žmogaus poreikius, norus, interesus, ịsitikinimus, kaip pagrindinė asmens augimo varomoji jẻga. Anot V. Lukošūnienės (2014), suaugusiojo mokymosi motyvaciją lemia jo poreikiai ir interesai, kuriuos mokymasis gali patenkinti. Mokydamasis suaugęs žmogus orientuojasi ne ị patị mokomaji dalyką, o ị gyvenime kylančiu problemų sprendimą, tad motyvuotas mokytis yra tiek, kiek, jo manymu, tai padès minètas užduotis atlikti. Tikslinga pabrèžti, kad mokymo turinio kūrimo kontekstą naudinga sieti su darbuotojų profesinio prisitaikymo, arba profesinio augimo, motyvacija. Mažmeninės prekybos rinkoje, norint išlikti konkurencingam, reikia nuolat mokytis profesinès veiklos situacijose. Svarbu pažymèti, kad mokymasis bus tuo veiksmingesnis, kuo tiksliau bus numatyti konkretieji tarpiniai mokymosi tikslai, išreikšti atitinkama elgsena, mokymosi sąlygos, kuriomis pasireikš ši elgsena, bei mokymosi sèkmès kriterijai. Gauti rezultatai atskleidžia, kad tiriamieji pasiryžta keistis / mokytis, kai jaučia neatitikimą tarp to, kas jie yra, kokių žinių turi, ir to, ką norètų pasiekti. Todẻl apklaustieji kaip vieną iš veiksmingo mokymosi sąlygų ir nurodė tinkamą mokymosi tikslų iš(si)kèlimą.

7 lentelè. Veiksmingą mokymąsi lemiantys veiksniai

\begin{tabular}{|c|c|c|}
\hline \multirow{2}{*}{ Veiksmingą mokymąsi lemiantys veiksniai } & \multicolumn{2}{|c|}{ Atsakymai } \\
\hline & $n$ & proc. \\
\hline Tinkamai atlikta mokymosi poreikių analizė & 25 & 35,7 \\
\hline Palankios mokymosi aplinkos kūrimas & 10 & 14,3 \\
\hline Tinkamų mokymosi tikslų iškèlimas & 30 & 42,9 \\
\hline $\begin{array}{l}\text { Tinkama, bendravimu ir bendradarbiavimu pagrista lektoriaus ir } \\
\text { besimokančiojo sąveika }\end{array}$ & 22 & 31,4 \\
\hline Motyvacija tikslingai įsisąmoninti mokymosi turinį & 33 & 47,1 \\
\hline Mokymo formų / metodų ir medžiagos tinkamas parinkimas & 27 & 38,6 \\
\hline $\begin{array}{l}\text { Déstoma mokymo tema (dalykas), turinys ir tikèjimas mokymosi } \\
\text { naudingumu }\end{array}$ & 18 & 25,7 \\
\hline $\begin{array}{l}\text { Besimokančiuju grupès raida, dinamika (ivairovè), branda, } \\
\text { statusas, išsivystymo lygis, nuostatos, vertybès }\end{array}$ & 8 & 11,4 \\
\hline $\begin{array}{l}\text { Laikas, per kuri ịsisąmoninamos žinios, išlavinami gebèjimai, } \\
\text { suformuojamos nuostatas ir pan. }\end{array}$ & 8 & 11,4 \\
\hline $\begin{array}{l}\text { Lektoriaus profesionalumas, kompetentingumas, gebejjimas ugdyti } \\
\text { besimokantiji }\end{array}$ & 26 & 37,1 \\
\hline
\end{tabular}

Analizuojant, kaip tenkinami darbuotojų mokymosi poreikiai, žvelgiant $\mathfrak{i}$ įmonès veiklos perspektyvą, paaiškejjo, kad 68,6 proc. apklaustujų lanko kursus, 67,1 proc. mokosi darbo vietoje, 55,7 proc. lanko seminarus, paskaitas. Taigi 
Rūta Marija Andriekienè, Gitana Tolutienė, Jūratė Kontautienè

dauguma prekybos vadovų mokymosi poreikius tenkina darbo vietoje (žr. 8 lentelę). Tai reiškia, kad tiek patys tiriamieji, tiek įmonès laikosi sistemingo nuolatinio atsinaujinimo požiūrio ir tai sieja su darbo vieta. Konkurencinèje verslo aplinkoje, kuri nuolat kinta, kartu su sparčia technologijų pažanga prekybos vadovams nuolat kyla profesinių situacijų, problemų, individualių atvejų, kai laikui spaudžiant yra priversti greitai priimti sprendimus. Todèl mokymosi procese konkreti patirtis transformuojama į aukštesnio lygio tikslingą veiklą - naujų situacijų poveikio išbandymą.

8 lentelé. Respondentų pasiskirstymas mokymosi poreikių tenkinimo būdų aspektu

\begin{tabular}{|c|c|c|}
\hline \multirow{2}{*}{ Mokymosi poreikių tenkinimo būdai } & \multicolumn{2}{|c|}{ Atsakymai } \\
\hline & $n$ & proc. \\
\hline Mokomieji renginiai & 24 & 34,3 \\
\hline Diskusijos & 13 & 18,6 \\
\hline Seminarai, paskaitos & 46 & 55,7 \\
\hline Konferencijos & 18 & 25,7 \\
\hline Kursai & 27 & 68,6 \\
\hline Stažuotės, komandiruotès & 22 & 31,4 \\
\hline Savarankiškas mokymasis & 38 & 54,3 \\
\hline Mokymasis darbo vietoje & 47 & 67,1 \\
\hline Vaizdo pratybos (kalbèjimas prieš vaizdo kamerą) & 9 & 12,9 \\
\hline Imitaciniai žaidimai & 27 & 38,6 \\
\hline Ankstesnès patirties refleksija (patirtinis mokymasis) & 35 & 50,0 \\
\hline Mokymasis grupèse & 30 & 42,9 \\
\hline Mokymasis mokant kitus & 32 & 45,7 \\
\hline
\end{tabular}

Atliekant tyrimą paaiškèjo, kad tiriamiesiems tobulinti profesionalumą labiausiai padeda šios mokymosi formos: tęstinis profesinis mokymas ir kvalifikacijos tobulinimas (45,7 proc.); savišvieta (42,9 proc.). Panašu, kad daugelis respondentų mano, jog profesinis tobulejimas labiau susijęs su darbo vieta, o ne su formaliuoju švietimu. Tyrimo duomenys atskleidžia prekybos vadovų siekị savarankiškai kokybiškai ir kūrybiškai veikti tam tikroje profesinejje srityje, ieškoti naujų žinių ir praktiškai jas išbandyti. Kadangi respondentai prioritetą teikia tęstiniam profesiniam mokymui, kvalifikacijos tobulinimui ir savišvietai, vadinasi, jie supranta, kad šiu mokymosi formų esmè - skirtumas tarp turimų ir siekiamų igyti kompetencijų, susijęs su darbuotojų turimu kompetentingumu, jo ugdymu, kvalifikacijos tobulinimu, savišvieta, kuri svarbi profesiniam tobulèjimui, neatsiejamam nuo konkrečios darbo vietos, sprendžiamų problemų, individualių atvejų. 
Tyrimu nustatyta, kad maždaug pusė (51,4 proc.) apklaustujų mano, jog prekybos vadovų profesionalumo tapsmui įmonès taiko stebejjimą / vertinimą; kita pusė (50,0 proc.) pažymėjo prekybos vadovų savivaldų mokymąsi (savistabą, savianalizę, savimoką)(9lentelè). Remiantis tyrimo duomenimis, darytina prielaida, kad prekybos vadovams ịmonès užtikrina grįžtamojo ryšio dèl savo vykdomos veiklos ir jos rezultatų galimybę. Vadinasi, įmonès skatina savišvietą, o prekybos vadovai laikosi „nuostatos mokytis“. Tai rodo jų atsakomybę, ịsipareigojimą už savo profesionalumo tapsmą. Suaugęs žmogus turi ịsipareigoti ne tik profesijai, darbui, t. y. lavintis, bet ir šeimai, pomėgiams, todèl suaugusiojo savivaldumas aiškinamas kaip ypatinga profesionalumo tobulinimo strategija. Galima teigti, kad savivaldus mokymasis prekybos vadovams ypač svarbus. Svarbu ir tai, kaip juos vertina įmonès, nors daug dèmesio skiriama savistabai, savianalizei ir savimokai.

9 lentelè. Respondentų pasiskirstymas profesionalumo tobulinimo strategiju, padedančių tapti profesionalais, pasirinkimo aspektu

\begin{tabular}{|c|c|c|}
\hline \multirow{2}{*}{ Profesionalumo strategijos } & \multicolumn{2}{|c|}{ Atsakymai } \\
\hline & $n$ & proc. \\
\hline Stebèjimas / vertinimas & 36 & 51,4 \\
\hline Projektinė veikla & 13 & 18,6 \\
\hline Studijų grupès (dalijimasis darbo patirtimi su kolegomis) & 18 & 25,6 \\
\hline Savivaldus mokymasis (savistaba, savianalizè, savimoka) & 35 & 50,0 \\
\hline Veikla, atliekama patarejjui (mentoriui, treneriui) vadovaujant & 13 & 18,6 \\
\hline Nuolatinė kolegų, vadovų parama / pagalba & 28 & 39,6 \\
\hline Kvalifikacijos vertinimas ir analizè & 30 & 42,6 \\
\hline Kita & 3 & 4,3 \\
\hline
\end{tabular}

Dauguma (47,1 proc.) apklausos dalyvių pažymėjo, kad jų įmonėse mokymus vykdo prekybos vadovas; 44,3 proc. - personalo skyriaus darbuotojas. Akivaizdu, kad prekybos vadovams būtinos andragogo kompetencijos, nes baigę vadybos ar kitas studijas jų neigyja. Remiantis tyrimo duomenimis, respondentai labiausiai sutinka su tuo, kad asmuo, kuris organizuoja ir vykdo suaugusiujų mokymus, turi tureti bendrųų $(4,36)$ ir socialinių $(4,34)$ kompetencijų (1 pav.). Vadinasi, apklausos dalyviai nežino, kad vykdant mokymus suaugusiesiems svarbu turèti andragogo, tyrèjo ir edukacinių kompetencijų. Pastebėtina, kad respondentai prekybos vadovams nurode kitas būtinas kompetencijas nei asmeniui, kuris organizuoja ir vykdo mokymus darbuotojams. Tik trečdalis $(29,1$ proc.) tyrimo dalyvių mano, kad būtinos edukacinès kompetencijos. Didžioji dalis (78,6 proc.) atsakè, kad būtinos vadybinès, 64,3 proc. - strateginès ir 54,3 proc. - verslumo kompetencijos. Apklausos duomenys atskleidè, kad tiriamieji pažymèjo tas kompetencijas, kurios pagal svarbą tiesiogiai siejasi su prekybos vadovo darbu, 
atliekamomis funkcijomis. Šios trys kompetencijos ypač svarbios, kad prekybos vadovas savo idejjas igyvendintų profesinëje veikloje, planuotų ir vadovautų projektams: kūrybiškumas, domejjimasis naujovèmis, gebejjimas rizikuoti ir kt. Šiu specifinių žinių bei igūdžių nuolat reikia ịgyvendinant socialinius, ekonominius, komercinius ir kitus projektus. Be šiu kompetencijų, prekybos vadovams atliekant edukacinę funkciją būtina ịgyti andragogo kompetencijų, ypač edukacinès veiklos. Iš šių empirinių duomenų darytina išvada, kad edukacinèms prekybos vadovų kompetencijoms profesionaliai veiklai vykdyti dèmesio nedaug teskiriama.

Atlikus koreliacinę kompetencijų vertinimo ir išsilavinimo analizę, nustatytas statistiškai reikšmingas ryšys tarp išsilavinimo ir bendrujų $(r=0,330$, $p=0,005<0,01)$, išsilavinimo ir socialinių-emocinių $(r=0,288, p=0,016<0,05)$, išsilavinimo ir kognityvinių $(r=0,354, p=0,003<0,01)$, išsilavinimo ir procesiniu $(r=0,244, p=0,042<0,05)$ kompetencijų. Visais atvejais ryšys tiesioginis ir galima daryti išvadą, kad kuo aukštesnis išsilavinimas, tuo labiau pripažịstama šiu kompetencijų svarba.

Atlikus tyrimą atskleista: 37,1 proc. respondentų dèl edukacinès veiklos pažymėjo, kad labiausiai norètų tobulinti mokymosi poreikių analizès procesą, taikydami tam skirtas metodikas. Dél vadybinès veiklos didžioji dauguma (67,1 proc.) respondentų norètų lavinti mokymosi paslaugų teikimo planavimo, organizavimo ir koordinavimo gebejjimus. Dèl tiriamosios veiklos dauguma (65,7 proc.) tyrimo dalyvių, remiantis apklausos rezultatais, norètų išmokti numatyti praktinès veiklos tobulinimo galimybes, perspektyvias, veiklos tobulinimą skatinančias iniciatyvas. Bendrujų kompetencijų aspektu net 64,3 proc. tiriamuju noretų tobulinti gebejjimą priimti ir teikti grižtamajị ryšį: bendrauti, bendradarbiauti, prisiimti atsakomybę, dirbti komandoje ir kt. Tai rodo, kad prekybos vadovams trūksta gilesnių žinių ir gebèjimų elementariose bazinèse andragoginès veiklos srityse, be kurių neįmanoma arba įmanoma, bet nekokybiškai numatyti suaugusiųu mokymosi vizijas ir tikslus, perspektyvą, atlikti stebėseną ir pan.

Atlikus koreliacinę analizę, ar siekis tobulinti kompetencijas priklauso nuo amžiaus, išsilavinimo, darbo stažo, nustatyti statistiškai reikšmingi koreliaciniai ryšiai tarp išsilavinimo ir tiriamujų kompetencijų $(r=-0,256, p=0,032<0,05)$, išsilavinimo ir noro tobulinti bendrąsias kompetencijas $(r=-0,301, p=0,011<0,05)$. Abiem atvejais ryšys atvirkštinis. Galima daryti išvadą, kad kuo aukštesnis išsilavinimas, tuo mažiau norima tobulinti tiriamąsias ir bendrąsias kompetencijas. Be to, nustatytas statistiškai reikšmingas atvirkštinis koreliacinis ryšys tarp darbo stažo ir noro tobulinti bendrąsias kompetencijas $(r=-247, p=0,039<0,05)$, t. y. tiriamieji, turintys didesnị darbo stažą, statistiškai reikšmingai pažymi mažesni norą tobulinti bendrąsias kompetencijas. 
Iš tyrimo paaiškejjo, kad nemaža dalis $(22,9$ proc.) prekybos vadovų tobulina savo kompetencijas tik pasitaikius galimybei; 21,4 proc. - kasdien. Taigi prekybos vadovai, kaip profesionalai, mokymosi neatsieja nuo kasdienio gyvenimo ir patirties, ji mato kaip procesą, kur susiejamos turimos ir naujos patirtys, taip plečiant požiūrị, žinojimą, kompetenciją. Tyrimo duomenys atskleidè ir tai, kad didžioji dauguma (38,6 proc.) respondentų save laiko kompetentingais profesionalais; dauguma (37,1 proc.) - patyrusiais profesionalais; beveik ketvirtadalis (18,6 proc.) aukščiausio lygio profesionalais ekspertais. Tyrimo duomenys liudija, kad dauguma prekybos vadovų yra savo srities profesionalai ir gali remtis ankstesnèse veiklos situacijose taikyta bei patikslinta praktika, ją pritaikydami naujose situacijose.

Pastebèta, kad statistiškai reikšmingai kaip profesionalumo tobulinimo galimybes įvardija kvalifikacijos augimą tiriamieji iki $30 \mathrm{~m}$. bei $46 \mathrm{~m}$. ir vyresni nei 31-45 m. amžiaus $\left(\chi^{2}=8,446, p=0,015<0,05\right)$. Akivaizdu, kad jauniems prekybos vadovams kvalifikacijos tobulinimas suteikia būtinų žinių, lavina gebėjimus, formuoja požiūrị - tai, kas būtina profesinei veiklai. Tuo tarpu vyresnio amžiaus prekybos vadovai kvalifikacijos tobulinimą traktuoja kaip asmeninių interesų tenkinimo ir asmeninio tobulèjimo būdą. Taigi įmonès renkasi prekybos vadovų profesionalumo tobulinimą, kaip galimybę ugdyti kompetencijas ir gerinti profesinès veiklos kokybę.

Kiti empiriniai duomenys atskleidžia, kokie profesionalumo tobulinimo būdai respondentams atrodo veiksmingiausi: seminarai, paskaitos (64,3 proc.); mokymasis darbo vietoje (61,4 proc.) ir kursai (40 proc.) (žr. 10 lentelę). Taigi dauguma respondentų veiksmingai siekia profesionalumo savo darbo vietoje, jiems priimtinesni trumpalaikiai seminarai, kursai, paskaitos. Palyginus, kaip skiriasi veiksmingiausių profesionalumo tobulinimo būdų pasirinkimas amžiaus aspektu, nustatyta, kad statistiškai reikšmingai skiriasi pasirenkant studijų grupes $\left(\chi^{2}=12,503, p=0,002<0,01\right)$. Šị būdą statistiškai reikšmingai dažniau pažymėjo $46 \mathrm{~m}$. ir vyresni respondentai, o tai rodo, kad vyresnio amžiaus prekybos vadovai, siekdami būti arčiau praktinès veiklos ir įmonès konteksto, kaip veiksmingiausią profesionalumo tobulinimo būdą ịvardijo pasidalijimą patirtimi, ịmonei aktualių problemų sprendimą ir rėmimąsi turimomis žiniomis bei patirtimi.

10 lentele. Veiksmingiausi profesionalumo tobulinimo būdai ir strategijos

\begin{tabular}{|l|c|c|}
\hline \multicolumn{1}{|c|}{ Profesionalumo tobulinimo galimybės } & \multicolumn{2}{c|}{ Atsakymai } \\
\cline { 2 - 3 } & $\boldsymbol{n}$ & proc. \\
\hline Mokomieji renginiai & 23 & 32,9 \\
\hline Diskusijos & 26 & 37,1 \\
\hline Seminarai, paskaitos & 45 & 64,3 \\
\hline Konferencijos & 22 & 31,4 \\
\hline Kursai & 28 & 40,0 \\
\hline
\end{tabular}


Rūta Marija Andriekienė, Gitana Tolutienė, Jūratė Kontautienè

\begin{tabular}{|l|c|c|}
\hline \multirow{2}{*}{\multicolumn{1}{|c|}{ Profesionalumo tobulinimo galimybės }} & \multicolumn{2}{c|}{ Atsakymai } \\
\cline { 2 - 3 } & $\boldsymbol{n}$ & proc. \\
\hline Stažuotės, komandiruotės & 21 & 30,0 \\
\hline Stebejjimas / vertinimas & 18 & 25,7 \\
\hline Dalyvavimas projektinejje veikoje & 23 & 32,9 \\
\hline Studijų grupės (dalijimasis darbo patirtimi su kolegomis) & 21 & 30,0 \\
\hline Savivaldus mokymasis (savistaba, savianalizė, savimoka) & 22 & 31,4 \\
\hline Veikla, patarèjui (mentoriui, treneriui) vadovaujant & 15 & 21,4 \\
\hline Nuolatinè kolegų, vadovų parama & 18 & 25,7 \\
\hline Kvalifikacijos vertinimas ir analizė & 16 & 22,9 \\
\hline Ankstesnės patirties refleksija & 19 & 27,1 \\
\hline Mokymasis darbo vietoje & 43 & 61,4 \\
\hline Speciali literatūra & 16 & 22,9 \\
\hline
\end{tabular}

Apibendrinant prekybos vadovų požiūrio ị veiksmingo mokymosi galimybes profesionalumo tobulinimo kontekste analizę, galima teigti, kad profesionalumą jie sieja su nuolatiniu profesinei veiklai būtinų kompetencijų ịgijimu ir tobulinimu. Prekybos vadovai yra linkę atsakingai mokytis, nes žvelgiant ị ateitị sistemingas tobulejjimas lemia profesionalumą. Pastaraji jie sieja su lankstumu priimant pokyčius, gebejjimu savo patirti pritaikyti kintančiose veiklos situacijose ir naujų galimybių paieška. Linkę tobulinti profesionalumą asmeniškai tobulėdami, kad pasiektų kuo didesnių darbo rezultatų, nes tai užtikrina verslo gyvavimą. Taigi prekybos vadovams asmeniškai naudinga ir būtina tobulinti savo profesionalumą, kad igyvendintų profesinès veiklos tikslus ir prisitaikytų prie nuolatinių prekybos rinkos pokyčių.

Veiksmingą mokymąsi supranta kaip mokymąsi taikant naujausius metodus, ịsisąmoninant nuolat atsinaujinančias žinias, igyjant naujų igūdžių, keičiant nuostatas. Tai lemia beveik kasdien atsinaujinančios naujos technologijos, darbo metodikos ir kt. Prekybos vadovų nuomone, mokymosi veiksmingumą lemia tinkami mokymosi tikslai, tikslingas mokymosi turinys ir tinkamos mokymosi formos pasirinkimas. Prekybos vadovams trūksta refleksijos ịgūdžių, ypač tiems, kurių profesinès veiklos patirtis nedidelè. Prekybos vadovų mokymosi poreikiai tenkinami imonių organizuojamuose kursuose darbo vietoje, seminaruose, paskaitose ir kt., t. y. jų profesinis tobulejjimas labiau susijęs su darbo vieta. Siekti profesionalumo leidžia tęstinis profesinis mokymas, kvalifikacijos tobulinimas, savišvieta. Imonèse taikomos stebejimo / vertinimo ir savivaldaus mokymosi strategijos.

Respondentų nuomone, prekybos vadovo profesionaliai veiklai vykdyti būtiniausios vadybinès, strateginès ir verslumo kompetencijos. Imonèse mokymus paprastai vykdo prekybos vadovai, tad jiems svarbu tobulinti arba igyti andragogo 
kompetencijų, ypač edukacinès veiklos. Didesnę profesinès veiklos patirtį turintys tiriamieji statistiškai reikšmingai pažymi mažesni norą tobulinti bendrąsias kompetencijas. Imonėse mokomasi kaupiant patirtị, pamažu ịsisąmoninant tą ribą, už kurios profesionalo kompetencijos pradeda skirtis nuo neturinčiojo patirties. Tad tiriamieji savo profesionalumo tobulinimo galimybes įvardija kaip praktinės patirties igijimą, kompetencijų, kvalifikacijos tobulinimą. Prekybos vadovų teigimu, veiksmingiausi profesionalumo tobulinimo būdai ir strategijos yra seminarai, paskaitos, mokymasis darbo vietoje, kursai ir kt.

\section{Išvados ir siūlymai}

Atliktas tyrimas atskleidè, kad prekybos vadovai profesionalumą sieja su nuolatiniu mokslo žinių ir kompetencijų, būtinų jų profesinei veiklai, igijimu ir tobulinimu. Prisiimdami atsakomybę už mokymąsi, žvelgdami ị perspektyvą prekybos vadovai profesionalumą sieja su lankstumu pokyčiams, gebejjimu savo patirti pritaikyti kintančiose profesinès veiklos situacijose, naujų galimybių paieška.

Prekybos vadovai veiksmingą mokymąsi supranta kaip mokymąsi taikant naujausius metodus, ịsisąmoninant nuolat atsinaujinančias žinias, ịgyjant būtinus igūdžius, keičiant nuostatas. Prekybos vadovų nuomone, mokymosi veiksmingumą lemia tinkami mokymosi tikslai, tikslingas mokymosi turinys ir tinkamas mokymosi formų parinkimas, bet veiksmingai mokytis siekiant profesionalumo jiems trūksta refleksijos ịgūdžių.

Prekybos vadovų profesionalumui tobulinti įmonèse taikomos šios strategijos: stebejjimas / vertinimas, savivaldus mokymasis. Veiksmingiausi profesionalumo tobulinimo būdai ir strategijos: seminarai, paskaitos, mokymasis darbo vietoje, kursai. Visa tai siejama su darbo vieta. Prekybos vadovams profesionalumą tobulinti padeda šios dvi mokymosi formos: tęstinis profesinis mokymas ir kvalifikacijos tobulinimas bei savišvieta. Prekybos vadovų nuomone, jų profesinei veiklai būtiniausios vadybinès, strateginès ir verslumo kompetencijos. Mažiausiai dèmesio jie linkę skirti edukacinių kompetencijų tobulinimui.

Tyrimo rezultatai atskleide, kad veiksmingo mokymosi galimybès siekiant profesionalumo prekybos vadovams sudarytos, kai i̇monèse tikslingai ir sistemingai organizuojamas veiksmingas jų mokymasis, leidžiantis ịmonėms spręsti dabarties ir būsimas problemas, prekybos vadovus motyvuojant tobulinti profesionalumą taikant veiksmingas strategijas ir būdus. Prekybos vadovų mokymąsi profesionalumo tobulinimo kontekste turètų organizuoti ir vykdyti andragogai profesionalai arba prekybos vadovai, ịgiję andragogo kompetencijų: edukacinių (gebantys vykdyti mokymosi procesus, tenkinti besimokančiuju 
Rūta Marija Andriekienė, Gitana Tolutienė, Jūratė Kontautienè

poreikius ir kt.), vadybinių (gebantys planuoti, koordinuoti mokymosi procesus, užtikrinti lygiavertę sąveiką, sudaryti mokymosi sąlygas ir kt.), tyrejo (gebantys tirti mokymosi poreikius ir kt.) ir bendrujų (gebantys sistemiškai mąstyti, užtikrinti grịžtamajị ryši ir kt.).

Remiantis empirinio tyrimo rezultatų analize ir išvadomis, pateikiama siūlymų mažmeninès prekybos įmonès vadovams:

- Teikti pasiūlymus administracijai dèl darbuotojų ir pačių vadovų mokymosi poreikių, numatyti jų vykdymo galimybes.

- Aktyviai įsitraukti i įmonès strateginio planavimo procesus, numatant darbuotojų ir pačių vadovų veiksmingo mokymosi siekiant profesionalumo galimybes.

- Kilus sunkumų dèl profesionalumo tobulinimo, kreiptis pagalbos, konsultuotis su administracijos darbuotoju, kuris atsakingas už mokymąsi, ar andragogą profesionalą.

\section{Literatūra}

Adomaitienė, J., Zubrickienė, I. (2020). Veiklos tyrimai, jų taikymo teorija ir praktika. Studijų knyga. Klaipėda: KU leidykla.

Adomaitienè, J., Zubrickienè, I. (2016). Projektai mokymo(si) procese: andragoginès sqveikos optimizavimo aspektas. Monografija. Klaipeda: KU leidykla.

Andriekienė, R. M. (2011). Andragogų profesionalizacija atliekamų vaidmenų aspektu. Andragogika, Nr. 2, p. 13-28. Klaipėda: KU leidykla.

Bagdonienè, A., Adomaitiené, J. (2017). Andragogų profesinis tobulèjimas atliekant veiklos tyrimus. Andragogika, Nr. 1 (8), p. 112-130. Klaipėda: KU leidykla.

Brookfield, S. D. (2013). Powerfull Techniques for Teaching Adults. San Francisco: Jossey-Bass; 1 edition.

Gedvilienè, G. ir kt. (2015). Suaugusiujų bendrujų kompetencijų plètra. Monografija. Vytauto Didžiojo universitetas, Versus Aureus.

Greene, C. L. (2016). Entrepreneurship: ideas in action. South-Western / Thomson.

Jatkauskienė, B. (2013). Andragogu profesionalizacijos sistemos procesionali raiška. Monografija. Klaipėda: KU leidykla.

Jatkauskienė, B., Andriekienė, R. M. (2013). Universiteto dėstytoju veiklos daugiafunkcionalumas profesionalizacijos kontekste. Monografija. Klaipėda: KU leidykla.

Jatkauskienė, B., Le Boterf, G. (2012). Universiteto dèstytojų profesionalizacijos eskizas. Andragogika, Nr. 1(3), p. 48-66. Klaipèda: KU leidykla.

Jatkauskienė, B., Trakšelys, K. (2015). Andragogy: Adult Education Contexts. Monografija. Scholar's Press, Saarbrücken (Vokietija).

Le, Boterf, G. (2010). Dar karta apie kompetenciją. 15 pasiūlymų ịprastoms idëjoms išplètoti. Klaipèda: KU leidykla.

Lukošūnienė, V. (2014). Kvalifikaciją tobulinančiu suaugusiujų mokejjimo mokytis kompetencijos raiška ir ugdymas (is). Vilnius: Lietuvos edukologijos universiteto leidykla.

Merriam, S. B. (2013). Adult Learning: Linking Theory and Practice. San Francisco: Jossey-Bass.

Syed, M. (2015). Black Box Thinking: Why Most People Never Learn from Their Mistakes-But Some Do. Portfolio.

Stelmokienė, A., Endriulaitienè, A. (2015). Vadovavimo efektyvumo vertinimas: psichologiniai aspektai. Monografija. Kaunas: Versus Aureus.

Tolutienè, G. (2014). Professional development on the aspect of learning from experience. Nauki Humannistyczne Humanities, Journal of Modern Science, No. 2, p. 13-26. WSGE.

Паронджанов, В. Д. (2017). Как написать хорочий учебник для хороших людей. Учебники, о которых мечтают студенты и икольники. Москва. 
PREKYBOS VADOVŲ VEIKSMINGO MOKYMOSI GALIMYBĖS PROFESIONALUMO...

\section{EFFECTIVE LEARNING OPPORTUNITIES OF TRADE SUPERVISORS IN THE PERSPECTIVE OF PROFESSIONALISM IMPROVEMENT}

\section{Rūta Marija Andriekienė, Gitana Tolutienè, Jūratė Kontautienė}

Summary

Today, both scientific and practical dialogues focus on improving employee skills, professionalism, organizational learning culture, unlocking potentials for an organization to succeed now and in the future, and to be superior in a competitive marketplace. Therefore, a modern successful organization strives to have employees who are professional and constantly improving. However, helping to develop the professionalism of employees from a perspective is not so easy in an organization. Companies should focus on developing promising, effective learning programs so that employees can learn quickly and efficiently, pursue professionalism, and increase the value and productivity of their work. Successful companies that develop professionals, i. y. improves their skills and abilities in the long run.

In this article, it is important to identify the learning effectiveness of trade supervisors in the perspective of professional development, which is inseparable from a person's internal values and emerging challenges in professional activities and life. As the analysis of the scientific literature has shown, the effective learning of trade supervisor from the perspective of professionalism improvement has not been sufficiently analyzed. Therefore, the article formulates the following: what are the opportunities for effective learning of trade supervisors in the perspective of professionalism improvement?

The object of the research: effective learning and professionalism improvement of trade supervisors.

The aim of the research: to investigate the possibilities of effective learning from the perspective of professionalism improvement from the point of view of trade supervisors.

The aim of the research was pursued by revealing the attitude of trade supervisors to: 1) the concept and essence of professionalism improvement, effective learning; 2) strategies and methods for effective learning and professionalism improvement; 3 ) competencies necessary for the professional activities of trade supervisors; 4) opportunities for effective learning of trade supervisors in the aspect of professionalism improvement.

Research methods. After the theoretical analysis of effective employee learning in the perspective of professionalism improvement, a survey (questionnaire) was 
conducted in order to examine the attitude of trade supervisors to the possibilities of effective learning in the perspective of professionalism improvement.

The study was conducted using a questionnaire. The questionnaire was compiled on the basis of theoretical analysis and questions and answer variants prepared by the authors of the article. 80 questionnaires were distributed, 70 of them were used for analysis. The study included trade supervisors working in retail businesses that vary by location, turnover, number of staff, time of establishment, and so on.

The analysis of socio - demographic data of the research participants showed that the largest part - 70 percent. the participants in the study were women and the rest were men. The research sample consists of respondents of various age groups, the majority of whom $(68.6 \%)$ are aged $31-45$. and about a quarter $(21.4 \%)$ are 46 years old. and older. The smallest part (10\%) is up to $30 \mathrm{~m}$. respondents. This shows that the majority of survey participants are middle-aged sales executives who have the opportunity to improve their professionalism in their professional field. It can be assumed that in this age, adults have reached the peak of working age, when the aim is to secure personal and professional life, actively pursue a career and improve their professionalism in activities. The analysis of the distribution of respondents by profession showed that as many as $71.1 \%$. the respondents have acquired a managerial education, which means that the profession acquired by the majority of respondents corresponds to the nature of the work.

The majority (47.1\%) of the respondents indicated that they have a higher university (bachelor's) degree, the other - a significant part (22.9\%) has a master's degree. This shows that the representatives of this profession are constantly striving to improve their professionalism. It was found that the majority $(67.1 \%)$ of respondents are older than 11 years. length of service. It can be assumed that most people are not working for the first year, have a higher education and are aware of what they lack in terms of professionalism improvement and are trying to improve in order to become professionals in their field.

Research shows that trade supervisors associate professionalism with the continuous acquisition and improvement of scientific knowledge and competencies required for professional activities. By taking responsibility for learning from a perspective, they associate professionalism with flexibility for change, the ability to adapt their experience to changing business situations, and the search for and creation of new opportunities.

Trade supervisors understand effective learning as learning using the latest techniques, absorbing ever-increasing and up-to-date knowledge, acquiring skills, changing attitudes. In their opinion, effective learning is determined by appropriate learning goals, purposeful learning content and appropriate selection of learning forms, but they lack reflection skills. 
The following strategies are used to improve the professionalism of trade supervisors in companies: monitoring / evaluation and self-directed learning, and the most effective ways and strategies for professionalism improvement - seminars, lectures, on-the-job training, courses. All this is linked to the workplace and helps to improve professionalism in these two forms of learning: continuing vocational training and in-service training, and self-education. In their opinion, managerial, strategic and entrepreneurial competencies are most needed to realize the professional activities of a trade supervisors. It pays the least attention to educational competencies.

The results of the research show that effective learning opportunities for trade supervisors in the perspective of professionalism improvement are created when effective training of trade supervisors is purposefully, continuously, systematically organized and implemented, which helps companies to solve problems now and in the future, when trade supervisors are motivated and improve professionalism with effective strategies and ways. The training of trade supervisors in the perspective of professionalism improvement should be organized and implemented by andragogues professionals or trade supervisors who have acquired andragogical competencies: educational competencies (be able to realize learning processes, meet the needs of learners, etc.); managerial competencies (to be able to plan, coordinate learning processes, ensure equal interaction, create learning conditions, etc.); research competencies (ability to research learning needs, etc.) and general competencies (ability to think systematically, provide feedback, etc.).

Based on the analysis of the results and conclusions of the empirical research, suggestions are made to the managers of the retail company:

- To provide proposals to the administration on the learning needs of the managed employees and the managers themselves and to anticipate the possibilities of their realization and implementation.

- To be actively involved in the strategic planning of the company, providing opportunities for effective learning of managers and managers themselves from the perspective of professionalism improvement.

- In case of difficulties in professionalism improvement, seek help, advice from the person in charge of administration or a professional andragogue.

Rūta Marija Andriekienė - profesorè, daktarè (socialiniai mokslai edukologija), Klaipėdos universiteto Socialinių ir humanitarinių mokslų fakulteto Tęstinių studijų centras.

El. paštas: ruta.andriekiene@ku.lt_ 